\title{
High Altitude Ramsar Sites of Nepal
}

\author{
Suraj Upadhaya ${ }^{1}$, Lina Chalise ${ }^{2}$ and Rajan P. Paudel ${ }^{3}$
}

\begin{abstract}
Nepal, signing in Ramsar Convention, has shown its willingness and commitment to wetland conservation. Himalayan wetlands are increasingly on limelight due to its vulnerability to Glacier lake outburst (GLOF), one of so called consequences of climate change. This article is a compilation of fact sheets about four high altitude Ramsar sites of Nepal: Gokyo and associated wetlands, Gosaikunda and associated wetlands, Phoksundo Lake and Rara lake.

रामसार अभिसन्धिमा हस्ताक्षर गरेर नेपालले सिमसार संरक्षणप्रति आफ्नो चासो र प्रतिबद्धता जाहेर गरेको छ। जलवायु परिवर्तनप्रति सम्बेदनशिलताको कारणले हिमालयमा अवस्थित सिमसारहरु चर्चामा छन्। यो लेखमा चार उच्च हिमाली सिमसार (गोक्यो, गोसाइकुण्ड, फोक्शुण्डो र रारा) को जानकारी समेटिएको छ।
\end{abstract}

Key Words: Gokyo, Gosaikunda, Phoksundo, Rara, High altitude wetlands

\section{Introduction}

Nepal is known for its abundant fresh water resources and counted among the world's top richest country in water resources. Beside this, Nepal also shares the world's limelight because of its rich biodiversity concentrated in narrow strip of land. Although Nepal is a landlocked country, it has many different types of wetlands that ranges from areas of permanently flowing rivers to areas of seasonal streams, high altitude glacial lakes, swamps, reservoirs, etc. The wetlands of Nepal are broadly divided into two categories as per its origin: natural and artificial. The natural wetlands comprise lakes and ponds, riverine floodplains, swamps, and marshes while artificial include water storage areas and deep water agricultural lands. Most of the lakes in high altitudes are Oligotrophic (least productive) and supports only a few aquatic macrophytes.

Himalayan Region though been able to catch up attention in globe for its vulnerability to climate change in recent years has always been ignored with few researches and studies in the area due to harsh climate and topography. But, high altitudes with its unique landscape, astounding biodiversity (endemic species) and recent realization as the Water Towers of the world prove itself worthy of more studies and researches. Highland (High altitude) represents more than 38 major ecosystem among 118 realized in the world (NBS 2002). Himalayan wetlands are unique ecosystems that fulfill important functions in the overall water cycle of the large Himalayan river basins that together serve close to $20 \%$ of the world's population.

\footnotetext{
${ }^{1}$ Kathmandu Forestry College, Kathmandu, Nepal, Email: luckysuraj@gmail.com

${ }^{2}$ Kathmandu Forestry College, Kathmandu, Nepal, Email: linachalise@gmail.com

${ }^{3}$ Kathmandu Forestry College, Kathmandu, Nepal, Email: rajanpoude1093@gmail.com
} 
The Himalayan wetland system comprises of networks of rivers with associated flood plain marshes and swamps, glaciers and hot springs, seasonal waterlogged areas and man made reservoirs.

\section{Wetlands and their importance}

Wetland (Simsar) is simply defined as a marsh, swamp or other area of land where the soil near the surface is saturated or covered with water, especially one that forms habitat for wildlife (Encarta, 2009).

Nepal's National Wetland Policy 2003 define wetlands as "natural or artificially created area, such as swamp, marsh, riverine floodplain, lake, water storage area and agricultural land containing water from underground water resources or atmospheric precipitation that may be permanent or temporary, static or flowing, and freshwater or saline". Broadly wetland is an ecotone between terrestrial and aquatic communities. The definition of wetland as used by the Convention on Wetlands is "area of marsh, fen, peat land or water, whether natural or artificial, permanent or temporary, with water that is static or flowing, fresh, brackish or salt, including areas of marine water, the depth of which at low tides does not exceed six meters". This definition is internationally accepted. Nepal has demonstrated its commitment to wetlands conservation by signing the Ramsar Convention on December 17, 1987 and by designating Koshi Tappu wetland in the Ramsar site (Paudel, 2009).

\section{Major policies guiding the conservation of the wetlands are:}

- $\quad$ Soil and Watershed Conservation Act 1982

- National Wetlands Policy 2003

- $\quad$ Nepal Policy and Action Plan 1993 and 1998

- Environmental Protection Act and Rules 1997

- Nepal Biodiversity Strategy 2002

- Ramsar Convention 1997

- National Parks and Wildlife Conservation Act 1973 (2029 BS)

Wetlands are the transitional zones between the terrestrial and aquatic systems (Bhandari et.al, 1994). Wetland ecosystems account for about $6 \%$ of the global land area and are among the most threatened of all environmental resources. They are also described as "the kidneys of the landscapes" due to their important functioning in the hydrological cycle. Their importance has risen today as a matter of fact that they are capable of acting as natural sink for carbon dioxide and climate stabilizers. Wetlands have intrinsic attributes, perform wonderful function and produce viable goods and services. Wetland habitats ensure high 
biodiversity of aquatic and semi-terrestrial plant and animal species. A variety of wetlands flora and fauna including 172 indigenous species of fish, over 130 species of waterfowl, many migratory birds are getting support from wetland ecosystem.

Box below shows wetlands values derived from attributes, functions, goods and services. This is mainly classified in four categories by Emeston.

\begin{tabular}{|c|c|c|c|}
\hline Direct Values & Indirect Values & Option Values & Non use Values \\
\hline $\begin{array}{l}\text { Production and } \\
\text { consumption goods } \\
\text { and services such as } \\
\text { fish, fuel, wood, sand, } \\
\text { water, building poles, } \\
\text { thatch, wild foods, } \\
\text { medicines, } \\
\text { agricultural/ } \\
\text { cultivation, } \\
\text { pasture/grazing, } \\
\text { transport, recreation }\end{array}$ & $\begin{array}{l}\text { Ecosystem } \\
\text { function such as } \\
\text { water quality, } \\
\text { water flow, } \\
\text { water storage, } \\
\text { water purification, } \\
\text { water recharge, } \\
\text { flood control, } \\
\text { storm protection, } \\
\text { nutrient retention, } \\
\text { micro climate } \\
\text { regulation }\end{array}$ & $\begin{array}{l}\text { Premium placed } \\
\text { on possible } \\
\text { future uses and } \\
\text { application, } \\
\text { pharmaceutical, } \\
\text { agricultural, } \\
\text { industrial, } \\
\text { leisure, } \\
\text { water use }\end{array}$ & $\begin{array}{l}\text { Intrinsic } \\
\text { significance in } \\
\text { term of cultural } \\
\text { value, } \\
\text { aesthetic value, } \\
\text { heritage value, } \\
\text { bequest }\end{array}$ \\
\hline
\end{tabular}

\section{High altitude Ramsar sites of Nepal}

In Nepal, wetland ecosystem is one of the most viable ecosystem among 118 ecosystems. Among numerous wetlands present in Nepal, 9 wetlands are recognized as a Ramsar Site, wetlands of international importance. Among nine Ramsar sites, four are located in high altitude. High altitudes wetlands are regarded as "any wetland types that are found above the elevation of 3,000 masl" (Bhandari, 2005). In 23.09.2007, four high altitude wetlands are recognized as Ramsar Sites. The remote location, pristine state, connection with local culture and its habitat providing function for various life forms make these wetlands valuable. The health of these wetlands is of major significance to a vast population not just upstream but to the area downstream as well.

\begin{tabular}{|c|c|l|l|c|c|c|}
\hline SN & $\begin{array}{c}\text { Ramsar } \\
\text { Site No }\end{array}$ & \multicolumn{1}{c|}{ Name } & Location & $\begin{array}{c}\text { Date of } \\
\text { designation }\end{array}$ & $\begin{array}{c}\text { Area } \\
\text { (ha) }\end{array}$ & $\begin{array}{c}\text { Elevation } \\
\text { (masl }\end{array}$ \\
\hline 1 & 1692 & $\begin{array}{l}\text { Gokyo and } \\
\text { associated Lakes }\end{array}$ & Solukhumbhu & 23.09 .2007 & 7,770 & $4,700-5000$ \\
\hline 2 & 1693 & $\begin{array}{l}\text { Gosaikunda and } \\
\text { Associated lakes }\end{array}$ & Rasuwa & 23.09 .2007 & 1,030 & $4,000-$ \\
4,700
\end{tabular}

Source: http://www.ramsar.org/sitelist_order.pdf 


\section{Gokyo and associated wetlands:}

\section{General features}

- Coordinates: $27^{\circ} 57.02^{\prime} \mathrm{N}$

- Length: $\quad 975 \mathrm{~m}$

$86^{\circ} 41.58^{\prime} \mathrm{E}$

- Wetland type: glacier Lake, oligotrophic

- Biological significance: Consist of 4 endemic species of plants and is a suitable habitat of Brahminy duck

\section{Overview}

A system of glacial lakes located in the Sagarmatha National Park, Gokyo \& associated lake is a UNESCO's world Heritage Site. It is located at an altitude between 4,700m$5000 \mathrm{~m}$ in high Himalayan region at the base of Cho Oyo Mountain. The alpine pasture meadow and sloping mountain terrain support a number of IUCN Red listed rare and vulnerable species, endemic flowering plant and many important birds. Over 80 species of flowering plants have been recorded from the catchments. The system is a vital source of water for downstream communities.

Biodiversity values

- List of endemic species

1. Kobresia fissigulmis

2. Kobresia gandakiensis

3. Pedicularis poluninii

4. Pedicularis psuedoregelina

- List of vulnerable flora

1. Neopicrorhiza scrophulariifolia

2. Swertia multicaulis

3. Saussurea gossipiphora

4. Meconopsis horridula

- Fauna

1. Musk deer (Muschus chrysogaster)

2. Brahminay ducks (Tadorna ferruginnea)

3. Eurasian Wigeon(Anas penelope) 
4. Common Pochard (Aytha ferina)

5. Common Coot (Fulica atra)

6. Wood snipe (Gallinago nemoricola)

7. Eurasian Woodcock (Scolopax rusticola)

8. Great Crested Grebe (Podiceps cristatus)

\section{Socio-cultural and religious value}

A holy site for both Hindu and Buddhist, with common understanding of "no harm" to wetland birds promotes a safe habitat site as well as major tourist site is situated at Everest Base Camp which enhances its cultural and social values.

\section{Threats}

1. Unmanaged grazing practice in summer

2. Potential Glacier Lake Outburst Floods (GLOFs)

3. Pollution created by tourist

4. Over harvesting of dhupi (Juniperus sps) for firewood

\section{Gosaikunda and associated lakes}

\section{General features}

- Coordinates: $28^{\circ} 5.00^{\prime} \mathrm{N}$

$85^{\circ} 24.966^{\prime} \mathrm{E}$

- Length: $625.55 \mathrm{~m}$

- Wetland type: alpine fresh water

- Biological significance: Consist of endemic and threatened plant spp. and has high tourism potential.

- Hydrological significance: Consists 1.472 million cubic meter water volume and discharges 60 liter of water per second through outlet. Inlet discharge is 35 litres per second.

\section{Overview}

Gosaikunda and associated wetlands is located in Dhunche and Syafru VDCs of Rasuwa district and is about one and half days walk from Dhunche, the headquarter of Rasuwa. The freshwater wetland situated at $4260 \mathrm{~m}$ on the lap of hill Gosai, from where it burrows its name. Gosaikunda lake system of Langtang National Park ( 54 ha as water bodies covered by 16 lakes with 1,030 ha as the catchment) is an important sources of water for the famous Trishuli river of Nepal (Karki, 2007). Within Langtang National Park, this Ramsar sites inhabit a considerable number of IUCN Red listed endangered and vulnerable species of 
fauna and flora. This lake is of significant religious value. Every year in the day of Janaipurnima and Dashain festival, thousands of national and foreign pilgrim climb up the hill and take a bath in this holy kunda (lake).

\section{Biodiversity values}

- $\quad$ Flora

About 100 species of flowering plants have been recorded from the Gosaikunda catchment. It is one of the most important sites for collection of type specimens of plants for botanical purpose. It also holds endemic species of plants along with other threatened species.

\section{- List of threatned flora}

1. Jatamanshi (Nardostachys grandiflora): Vulnerable

2. Kutki (Neopicrorhiza scrophulariflora): Vulnerable

3. Bikh (Aconitum spicatum): Vulnerable

4. Chiratio (Swertia multicaulis): Data deficient

5. Himalayan poppy (Meconopsis dhwojii): Nearly threatened

6. Bhutkesh(Heracleum lalii): Endangered

7. Jurinea dolomiaea: Nearly threatened

8. Padamchal(Rheum australe): Vulnerable

9. Padamchal (Rheum moorcoftianum): Nearly threatened

- Endemic plants

1. Himalayan poppy (Meconopsis dhwojii)

2. Golden Primerose (Primula aureate)

3. Bhutkesh (Heracleum lalii)

4. Pedicularis pseudoregeliana

5. Suryamukhi(Cremanthodium nepalenesis)

6. Rhododendron cowanianum

- Fauna

\section{List of endangered and vulnerable fauna}

1. Snow leopard (Uncia uncia): Endangered

2. Musk deer (Muschus chrysogaster): Low risk / Near threatened

3. Red Panda (Ailurus fulgens): Endangered 
Phytoplankton 1,548 units/ml. (6 m. depth) with higher

1. Merismopedia sp.

2. Chlorobotrys $s p$.

3. Ankistrodsmus sp.

4. Dinobryon sp.

5. Glenodium $s p$.

6. Aphanotheca sp. and

7. Planktosphaeria sp.

Zooplankton were found 6.4x106 ind./m3 (20 m depth) -

1. Daphnia sp.- $52 \%$,

2. Cyclops sp.- $35 \%$, and

3. Napuliar larvae of Cyclops- $11 \%$.

\section{Socio-cultural significance}

Hindu mythology mentions Gosaikunda as a residing place of Hindu deities like Lord Shiva and Goddess Gauri. Hindu scriptures like Bhagawat and Bishnu Puran and Hindu epics like Ramayan and Mahabharat mentions Samundra Manthan (Sea exploring) which is directly related to the origin of Gosaikunda. It is believed that the lake originated when the trishul thrown by shiva pierced the wall and gangajal filled the pond. The holy water of Gosaikunda is used during Gangadashahara and Janai purnima (sacred thread festival) by thousands of people visiting the place from Nepal and India to celebrate the festival. People believe that after bathing in the lakes ones ancestors and they themselves can go to heaven. This area is equally famous for cheese of yak. The area is culturally rich with Tamang as major ethnic group.

About $25-30 \%$ of the tourist visiting Langtang National Park visit Gosaikunda area. The highest number of tourist visiting the park is 13,166 during 2000/2001 while it was 8,165 during 2007(Nepal tourism statistics, 2007).

\section{Phoksundo lake}

\section{General features}

- Coordinates: $\quad 82^{\circ} 55^{\prime}-83^{\circ} 00^{\prime}$ E Longitude

$29^{\circ} 10^{\prime}-29^{\circ} 15^{\prime} \mathrm{N}$ Latitude

- Length: $\quad 5.15 \mathrm{~km}$

- Breadth: $800 \mathrm{~m}$.

- Hydrological significance: water volume is $408.599 \mathrm{MCM}$ and discharge is 3.715 cu.m/sec. 


\section{Overview}

Within Shey Phoksundo National Park, Phoksundo lake, a glacial lake, is located near Rigmo village in Dolpa (Nepal's largest districts).Phoksundo lake is the oligotrophic and deepest lake in the country ever recorded. It is centre of endemism in the eastern Himalayan region and a vital source of fresh water for downstream and source of highest waterfall $(167 \mathrm{~m})$ in Nepal. The lake, alpine meadows, provides habitat for a number of rare and vulnerable flora and fauna such as Snow Leopard (Unicia unicia), Musk deer (Moschus chrysogaster) and Tibetan Wolf(Canis lupus). The site also provides habitat for endangered bird Wood Snipe and many water birds. The site has great cultural and religious importance. The site is dominated by the endemic ancient religion named 'Bon-Po'.

\section{Biodiversity values}

\section{- Flora}

About 155 species of flowering plants have been recorded from the catchment.

Threatened species according to IUCN category are

1. Neopicrorhiza scrophulariifolia: Vulnerable

2. Dactylorhiza hatagirea, Dioscorea deltoidea: Critically Threatened

3. Aconitum spicatum: Vulnerable

4. Nardostachys grandiflora: Vulnerable

5. Podophyllum hexandrum: Vulnerable

6. Megacarpea polyandra: Vulnerable

\section{- Fauna}

The winter habitat of snow leopard and musk deer.

Birds found in catchments are

1. Red-crested Pochard (Rhodonessarufina)

2. Ruddy Shelduck (Tadorna ferruginea)

3. Common Moorhen (Gallinula chloropus)

4. Common Coot (Fulica atra)

5. Eurasian Wigeon (Anas penelope)

6. Bar-headed Goose (Anser indicus)

7. Brown dipper(Cinclus pallasii)

8. White-throated Dipper (Cinclus cinclus)

9. Wood Snipe (Gallinago gallinago) 


\section{Socio-cultural and religious value}

More than 20 Chhottens in southern belt and one Gumba in eastern site of the lake, where annual pray and worship occurs. Traditional Tibetan culture in upper Dolpo and Buddhism and ancient culture of Tibet called Bon-Po religion in lower Dolpo including Ringmo (Tsho) village enrich the area. It is a freshwater source for down stream people.

\section{Threats}

1. Pollution by resident local people due to habit of open toilet and other domestic use.

2. Over grazing.

3. Unsustainable collection of NTFPs for traditional use and illegal theft.

\section{Conservation measures}

User committees and groups are formed under the buffer zone program. Amchis groups are formed for the farming, conservation and sustainable use of NTFPs. Local people are managing camping site and home stay tourism.

\section{Rara lake}

\section{General features}

- Coordinates: $\quad 29^{\circ} 31^{\prime} 25^{\prime \prime}-29^{\circ} 32^{\prime} 47^{\prime \prime}$ N Longitude

- Length: $\quad 5.1 \mathrm{~km}$

- Width: $2.7 \mathrm{~km}$

- Depth: $\quad \operatorname{Max}(167 \mathrm{~m})$ and Avg. $(100 \mathrm{~m})$

- Shoreline: $\quad 14.0 \mathrm{~km}$

- Volume of water: $0.98 \times 109$ cubic meters

- Drainage: Lake drains to Mugu Karnali River via Nijar River

- Wetland Type: Permanent fresh water lakes, Alpine wetlands.

- Biological significance: Three endemic species of snow trout Asala macha (Schizothorax macropthalus, S. nepalensis, and S. raraensis), endemic frog Rara paha (Paa rarica), aquatic plants, protected in the park and has high tourism potential.

- Hydrological values: Ground water recharge through sediment trapping.

- Ecological significance: Dominated vegetation is blue pine and herbs, marshlands, and tussock grassland surrounds the lake.

\section{Overview}

The heaven on earth "Rara Lake", also known as Mahendra Lake, is situated at the altitude of $2990 \mathrm{~m}$. It is the largest lake of Nepal (10.8sq.km with depth $167 \mathrm{~m})$ situated in the 
smallest park Rara National Park with an area of 106sq.km. The lake drains to MuguKarnali River via Nijar khola. The lake is oval shaped with an east-west axis, and has a maximum length of $5 \mathrm{~km}$ and a width of $3 \mathrm{~km}$. Rara fulfills many of the requirements for being listed as the important Ramsar site. The tourism base of the social economy is dependent on wetland. An outstanding snowcapped panorama of Dolpo and Tibetan mountains overshadows the scene across the deep clear waters of the lake.

\section{Importance}

Some endemic plants found along Rara lake including Karnali river catchments are Nirbishi kyasar, Primula poluninii, Cirsium flavisquamatum. Some endemic fauna found in the area are amphibian Rara paha. Out of eight endemic fish species found in Nepal, three of them - Snow trout, Asala macha (Schizothorax macropthalus, S. nepalensis, S. raraensis) are found in Rara Lake( Karki et.al, 2007). Smooth otter (Lutra perspicillata) is well represented mammal in the Lake. Snow leopard sometime passes through the upper part of the catchment (Chuchemara lake).

Rara can be a major tourist destination; the highest number of tourist visiting the park was 560 individuals during 1997-1998, which have declined to 87 in 2007. In order to promote domestic and international visit, Rara Festival was promoted by tourism board in early 2007 (Nepal tourism statistics, 2007).

\section{Biodiversity values}

- List of endangered and vulnerable fauna:

1. Musk deer (Moschus chrysogaster): Low Risk/Near threatened

2. Wood snipe (Gallinago gallinago): Vulnerable

3. Red panda(Ailurus fulgens): Endangered

4. Cheer pheasant (Catreus wallichii): Endangered

- List of threatened flora

1. Panchoule (Dastylorhiza hatagirea): Endangered

2. Jatamanshi (Nardostachys grandiflor): Vulnerable

3. Kutki (Neopicrorhiza scrophulariflora): Vulnerable

4. Satuwa (Paris polyphylla Smith): Vulnerable

5. Laghupatra (Podophyllum hexandrum Royle): Vulnerable

6. Louth Salla (Taxus buccata): Endangered

7. Bikh (Aconitum spicatum): Vulnerable

8. Ceropegia spp. 
9. Okhar (Juglens regia): Near threatned

10. Sugandhawal (Valeriana jatamasi): Vulnerable

11. Talispatra(Abies spectabilis): Low Risk

12. Pakhanbed (Bergenia ciliata): Critically threatned

13. Jhyau (Lichen spp)

14. Karkati shringi (Pistacia chinens)

15. Jangali painyu (Prunus carmesina): Rare

16. Silajit

\section{- Insects}

There are numerous insects which serve as food for different waterfowls.

1. Dytiscid beetle

2. Mayfly

3. Caddis fly

4. Watershrimp (Gammarus)

5. Snail (Limnea)

6. Ram's Horn (Planorbis)

\section{- Birds}

Of the 235 bird species recorded, 49 species use this area as their resting site of which are migratory. The globally threatened bird cheer pheasant (Catreus wallichii) is found in the catchment area (Salleri, Lamichur, Bamichur and Rara) in the southern slope.

1. Cheer Pheasant (Catreus wallicii)

2. Ruddy Shelduck (Tadorna ferruginea)

3. Common Coot (Fulica atra)

4. Eurasian Woodcock (Scolopax rusticola)

5. Brown Dipper (Cinclus pallasii)

6. Little Grebe (Tachybaptus ruficollis)

7. Wood Snipe (Gallinago gallinago)

8. Great Crested Grebe (Podiceps cristatus)

9. Black-necked Grebe (Podiceps nigricollis)

10. Common Kingfisher (Alcedo atthis)

11. Crested Kingfisher (Megaceryle lugubris)

12. Black-crowned Night Heron (Nycticorax nycticorax)

13. Great Cormorant (Phalacrocorax carbo) 
14. Gadwall (Anser strepera)

15. Mallard (Anas platyrhynchos)

16. Northern Shoveler (Anas clypeata)

17. Common Teal (Anas crecca)

18. Tufted Duck (Aythya fuligula)

19. Common Golden eye (Bucephala clangula)

20. Common Merganser (Mergusmerganser)

21. Common Coot (Fulica atra)

22. Solitary Snipe (Gallinago salitaria)

\section{Socio-cultural and religious values}

The main occupation of local community is agriculture and rearing of sheep and goat which is an age-old profession. Pastoralism based on transhumance is the main occupation. The extraction of medicinal herbs is the source of income. Thakuris former resident $(>200$ years ago) are dominant community. Land tenure/ownership belongs to Government of Nepal. Thakur Babas temple is located towards the SE corner of the lake 500m upwards. There is a belief that Thakur god had thrown an arrow to discharge the water of lake to reduce the potential damage by over flooding/damming. People are not much seen to be dependent on the daily livelihood directly on the lake.

\section{Challenges}

Major conservation problem is of over grazing and disturbances created by them like defecation. Similarly, unabated collection of fuel wood, timber and NTFP from the catchments area of Rara are also the problems the conservation officers have to tackle with. Similarly, wastes produced during the major festivals and by visiting locals and tourists are adding to the pollution of the lake. Main challenge is to incorporate the local people and their culture in the conservation and motivate and direct them towards the sustainability of the Rara.

\section{Threats to high altitude Ramsar sites}

* Unmanaged grazing practice

* Pollution created by tourist

* Potential Glacier Lake Outburst Floods (GLOFs)

* Human waste

* Deforestation around wetlands

* Unmanaged and unsustainable harvesting of medicinal and aromatic plants

* Encroachment

* Hunting and poaching

* Illegal fishing 


\section{Conclusion}

The global importance of wetland is well established from retaining habitat of endangered species to breeding ground for migratory birds and fishes and as a source of genetic material, thus, its conservation is felt crucial with the latest uprising trend of its depletion. Nepals' wetland is in no exceptional state with sky-rocketing population growth, rampant pollution, invasion of alien species, encroachment of the land, over exploitation of natural resources and sedimentation; wetlands are often found in vulnerable state despite tremendous effort of conservation. Maybe that's why the conservation awareness and campaign for wetland conservation are gaining so much momentum on recent days. But also due to lack of documentation on the overall picture of wetlands and their resources, it is always difficult to integrate wetland issues into national planning framework and processes. Signing in Ramsar convention, Nepal took an initiative towards "Wise Use of Resources" that is in accord to the condition to be followed by contracting party in Ramsar COP9 in 2005. This convention also made recommendation for adopting national policies, development of participatory method of inventories, management plans, integration of wetlands and national planning, capacity building in both national and local levels and mainstreaming of wetlands into production sectors. Nepal has been pioneer in bringing some of the most innovative ideas in the field of conservation be it community forestry programme or participation management of Annapurna Conservation Area and Kanchenjunga Conservation Area. So, there is need of incorporation of field knowledge or indigenous knowledge with proper guidance from policy and technical papers. One of the drawback found in wetland conservation is absence of guidelines in order to implement policy like Nepal Wetland Policy and Nepal Biodiversity Strategy.

\section{Reference}

Bhandari, B., Shrestha, T. B. and McEachern, J.(Eds.).1994. In Safeguarding Wetlands in Nepal, proceedings of the National Workshop on Wetlands Management in Nepal, 3-5 March 1993. Kathmandu, IUCN, Nepal.

Bhandari, B. 2005. In High Altitude Wetlands of Nepal: Views and Reviews on Conservation proceedings of the National Workshop on High Altitude Wetlands of Nepal.Kathmandu: FEM.

Bhandari.B.B,2009. Wise use of Wetlands in Nepal. Banko Jankari Special issue:010017.

Diwakar et.al, 2009. Ecological study of Ghodaghodi lake. Banko Jankari Special issue:018-023.

His Majesty’s Government of Nepal 2059. National Wetland Policy (2003). Ministry of Forests and Soil Conservation.

HMGN/MFSC 2002. Nepal Biodiversity Strategy. 
Karki, J. et.al. 2007. High Altitude Ramsar Sites in Nepal: Criteria and Future Ahead. The Initiation 1(1):009-015

Laudari H.K,2008.An introduction to Ramsar listed Wetlands of Nepal:A literature review.The Nature:1(1):022-029.

Mahat et.al, 2008. Conserving Nepalese Wetlands: Status, Problems and Prospects. Biodiversity Conservation efforts in Nepal. ,DNPWC:022-026.

Nepal tourism statistics, 2007

Poudel B.S., 2009. Wetland conservation in Nepal : policies, practices, problems and possibilities. Banko Jankari Special issue:005-009. Ramsar sites in order of addition to the Ramsar List of Wetlands of International Importance,

Shrestha, T. B. and Joshi, R. M. 1996. Rare, Endemic and Endangered Plants of Nepal. WWF Nepal Program, Kathmandu.

WWF. Fact Sheet on Rara lake

http://www.ramsar.org/sitelist_order.pdf

http://www.encarta.msn.com 